\title{
APPLICATION OF GENETIC ALGORITHM TO MINIMIZE HARMONIC IN MULTILEVEL INVERTER
}

\author{
Firmansyah Nur Budiman $^{1 *}$, Novie Ayub Windarko ${ }^{2}$, Son Kuswadi ${ }^{3}$ \\ ${ }^{1}$ Jurusan Teknik Elektro, Fakultas Teknologi Industri, Universitas Islam Indonesia \\ ${ }^{2}$ Teknik Elektro Industri, Departemen Teknik Elektro, Politeknik Elektronika Negeri Surabaya \\ ${ }^{3}$ Teknik Mekatronika, Departemen Teknik Mekanika dan Energi, \\ Politeknik Elektronika Negeri Surabaya \\ *Corresponding author, e-mail: firmansyah.nur@uii.ac.id
}

\begin{abstract}
Abstrak-Dalam desain inverter, harmonisa tegangan merupakan permasalahan utama yang mempengaruhi performa inverter. Pada umumnya, kompleksitas permasalahan minimisasi harmonisa dipengaruhi oleh jumlah orde harmonisa yang akan diminimisasi. Paper ini membahas utilisasi algoritman genetika untuk menyelesaikan persoalan minimisasi harmonisa di inverter multilevel. Tujuannya adalah untuk menemukan hubungan antara jumlah orde harmonisa yang diminimisasi dan total harmonic distortion (THD) yang dihasilkan. Inverter yang diinvestigasi adalah inverter 11-level, akan tetapi studi ini bisa diaplikasikan ke inverter multilevel dengan jumlah level yang lain. Hasil studi menunjukkan bahwa harmonisa di tegangan keluaran inverter memiliki keterkaitan yang kecil terhadap jumlah orde harmonisa yang diminimisasi. Akan tetapi, hasil yang paling bagus tetap masih didapatkan ketika jumlah harmonisa yang diminimisasi banyak. THD terbaik yang diperoleh, dievaluasi hingga harmonisa ke-19, adalah 2,76\%, dimana angka ini cukup kecil dan dapat diterima.
\end{abstract}

Kata Kunci : Harmonisa, algoritma genetika, inverter multilevel dan optimisasi

\begin{abstract}
In inverter design, harmonic voltage is the main issue which affects the performance of the inverter. Generally, the harmonic minimization problem complexity is influenced by the number of harmonic orders to be minimized. This paper presents the utilization of genetic algorithm (GA) to solve harmonic minimization problem in multilevel inverter. The objective is to find relationship between the number of minimized harmonic orders and the results of total harmonic distortion (THD). The inverter to investigate is 11-level, but it is also applicable to multilevel inverters with any number of levels. The results show that harmonic contained in the output voltage has a small dependence on the number of harmonic orders that are minimized. However, the best results are still satisfied even though involving higher number of harmonics. The best-obtained THD, evaluated until $19^{\text {th }}$ harmonic, is $2.76 \%$, which is fairly low and thus acceptable.
\end{abstract}

Keywords : Harmonic, genetic algorithm, multilevel inverter and optimization.

Copyright (C) 2016 JNTE. All rights reserved

\section{INTRODUCTION}

Inverters play vital roles in power grid with penetration of renewable energy systems. They produce AC voltage from DC voltage generated by several renewable energy converters, such as photovoltaic [1]. This photovoltaic can directly be connected to AC main grid or be connected to DC bus first, together with other DC voltage producers, and then connected to AC main grid through an inverter [2].

Special type inverter that involves several two-level inverters arranged together is called multilevel inverters. These inverters have received worldwide reception due to their advantages, such as capability of high voltage operation, low switching losses (due to low switching frequency), high efficiency, and low electromagnetic interference (EMI) [3] - [5]. Their applications in power systems are mainly to convert DC to AC. The DC source is produced by various distributed energy sources, such as batteries, fuel cells, solar cells, rectified wind turbines, etc. Therefore, reliable connection can be established between micro grid and main grid. Multilevel inverters are fed by several DC sources of equal as well as unequal voltages [6]. 
Instead of producing square-wave output as the conventional two-level inverters do, multilevel inverters output waveforms are in a stepped form (more like sinusoidal waveform), which results in lower harmonics. However, the harmonics need to be minimized further in order to satisfy maximum criterion for THD, e.g. $5 \%$ according IEEE standard for THD of current [7]. The widely-used methods to control the output voltage of multilevel inverters include various multilevel sinusoidal PWM and space-vector PWM [8] - [9], but they increase control complexity and switching frequency. Another technique is called selective harmonic elimination (SHE) or programmed PWM [10].

Solving SHE problem using soft computation techniques have been becoming popular nowadays as compared to calculus-based method. The main advantage of soft computation techniques is their capability of solving nonlinear mathematical problems in a nonconventional way [11]. The availability of soft computation built-in tools in several softwares even makes it easier to utilize soft computation techniques to solve engineering problems.

In this paper, one of the most popular soft computation techniques, called genetic algorithm (GA), is used to minimize low-order harmonics in multilevel inverter until certain limits. The contribution of this study is an investigation resulting in a knowledge about the relationship between number of harmonics that are minimized and the THD. It is shown that in most cases, the number of minimized harmonic orders indeed determines the THD of the output voltage. However, the relationship is not strictly linear, in the sense that higher number of minimized harmonic orders does not always guarantee lower THD. Thus, it is worth to consider the targeted THD when designing the inverter. If the THD is required to be as small as possible, then minimization of higher number of harmonic orders scheme can be used. On the other hand, if the THD is only required to be less than a certain value, e.g. $5 \%$, it is not always necessary to employ such a scheme.

\section{MULTILEVEL INVERTER}

The most-commonly used multilevel inverter is series connection of several H-bridge inverter units. Each unit is powered by an independent DC source, which may be battery, super capacitor, fuel cell, solar cell, etc. In this paper, a single-phase 11-level inverter, whose structure and output voltage waveform are shown in Fig.1, is employed to perform study. This study only considers multilevel inverter with equal DC sources. The output voltage of the inverter $v_{0}$ is the sum of H-bridge voltages, i.e. $v_{0}=v_{1}+v_{2}+$ $v_{3}+v_{4}+v_{5}$. Each inverter unit is able to generate three voltage levels, i.e. $+V_{d c}, 0$, and $-V_{d c}$, depending on the state of its four switching devices. The level number of the inverter output voltage $m$ is given by $m=2 s+1$, where $s$ is the number of DC sources. Thus, an 11-level inverter has 5 independent DC sources, as clearly shown by Fig. 1 .

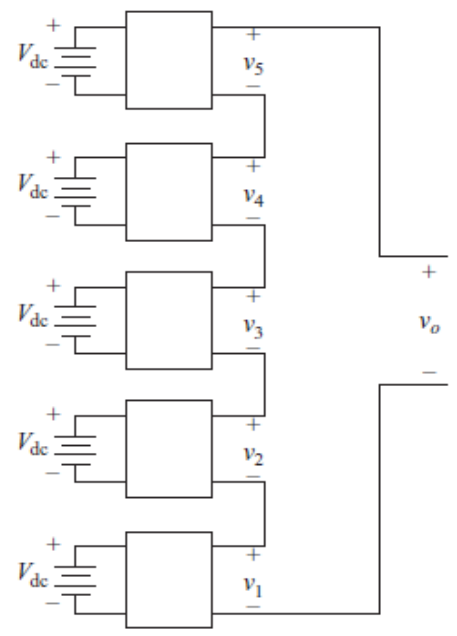

(a) Structure

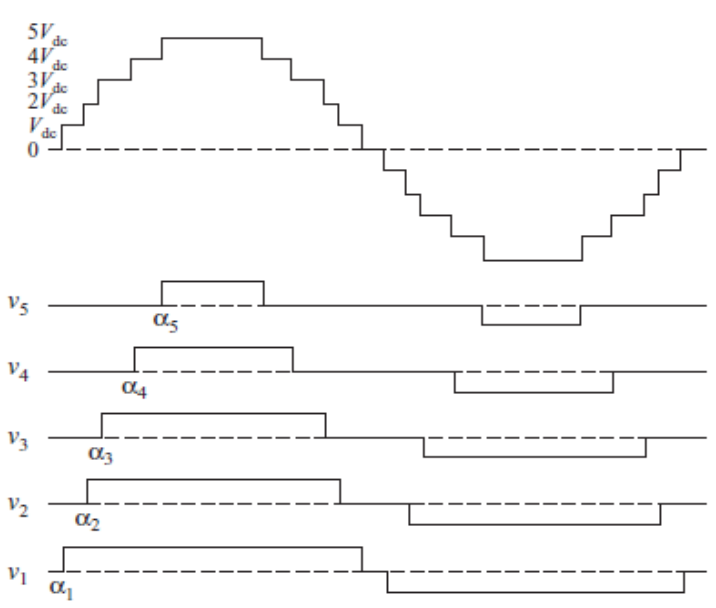

(b) Output voltage waveform

Figure 1. (a) The structure and (b) output voltage waveform of a single-phase 11-level inverter 
The Fourier expansion of the output voltage waveform using the SHE-PWM is expressed by

$$
v_{0}(t)=\frac{4 V_{d c}}{n \pi} \sum_{n=1,3,5, \ldots \sin (n \omega t)}^{\infty} \begin{aligned}
& \left(\cos \left(n \alpha_{1}\right)+\cos \left(n \alpha_{2}\right)\right. \\
& \left.+\ldots+\cos \left(n \alpha_{k}\right)\right)
\end{aligned}
$$

where $\alpha_{1}, \alpha_{2}, \ldots, \alpha_{k}$ are switching angles of each H-bridge unit and $k$ is 5 in case of 11-level inverter. The switching angles must satisfy the following constraint

$$
0 \leq \alpha_{1} \leq \alpha_{2} \leq \ldots \leq \alpha_{k} \leq \frac{\pi}{2}
$$

\section{GENETIC ALGORITHM}

Contoh isi bagian metodologi yang digunakan dalam menyelesaian masalah dari artikel yang akan diterbitkan pada Jurnal Nasional Teknik Elektro. The main idea of genetic algorithm (GA) is to solve optimization problem by mimicking genetic processes and theory of evolution. Thus, it involves several processes which sound like genetic terms, including reproduction, crossover, mutation, etc. GA was initially introduced by John Holland in 1960 s, who proposed the idea of moving from one population of "chromosomes" to another population using processes mentioned above. Minimization of a function $f\left(x_{1}, x_{2}, \ldots, x_{k}\right)$ using GA starts with coding of each $x_{i}$ as a binary or floating-point string. We prefer to use a binary string. Following is the example

$$
\begin{aligned}
& x_{1}=[10100 . .10011] \\
& x_{2}=[00110 . .01010] \\
& \vdots \\
& x_{k}=[11110 . .01011]
\end{aligned}
$$

In GA, the set of design variables $\left\{x_{1}, x_{2}, \ldots, x_{k}\right\}$ is referred to as chromosome and $x_{i}$ are genes. In short, there are several differences between GA and conventional optimizations, including random versus deterministic, population versus single best solution, etc [12].

\section{PROBLEM FORMULATION}

In this study, GA is employed to find switching angles of all $5 \mathrm{H}$-bridge converter units, i.e. $\left\{\alpha_{1}, \alpha_{2}, \alpha_{3}, \alpha_{4}, \alpha_{5}\right\}$, which result in minimum THD. GA application in this study is fully automated by built-in GA toolbox in MATLAB and involves the following steps.

1. Selecting binary string to code the chromosomes.

2. Determining the number of variables. In this study, as indicated above, there are 5 variables representing switching angles of 5 H-bridge inverter units which make up 11level inverter.

3. Making initial population. Higher population means we give more choices to the algorithm, thus it may improve the convergence rate. Fortunately, in MATLAB giving initial population is not a must, because it automatically provides an initial population with a size of 50 chromosomes.

4. Establishing objective function. As in "conventional" optimization, GA requires an objective function to be minimized. Several forms of objective function have been proposed in literatures. In [13] - [14], objective function is directly selected as the sum of several harmonic orders normalized to the fundamental or lower order harmonics. In [15], an interesting scheme was proposed which allows multiple switching in one level of the output voltage waveform. This study adopts the simplified form (fundamental frequency switching) of objective function in [15]. Considering up to 20 harmonics (for odd and non-triple harmonics), the objective function becomes

$$
\begin{aligned}
& f\left(\alpha_{1}, \alpha_{2}, \ldots, \alpha_{5}\right)= \\
& 100 \times\left[\begin{array}{l}
\left|M-\frac{\left|V_{1}\right|}{s V_{d c}}\right|+ \\
\left(\frac{\left|V_{5}\right|+\left|V_{7}\right|+\ldots+\left|V_{19}\right|}{s V_{d c}}\right)
\end{array}\right]
\end{aligned}
$$

where $M$ is the modulation index. Objective function (4) is subject to constraint (2). The numerator of the last term in (4) is the parameter to be varied throughout this study. For ease of analysis, the variation is listed in Table 1.

5. GA is usually set to run until certain number of generations (or 'iteration' in more familiar term). In this study, the GA iteration is stopped whenever "stall generation" is met, i.e. there is no immediate improvement. 
6. To evaluate the performance of the proposed study, switching angles given by GA optimization are used to calculate THD using the following expression

$$
T H D=100 \times \frac{1}{V_{1}} \sqrt{\sum_{n=5,7,11, \ldots}^{19} V_{n}{ }^{2}}
$$

THD values were evaluated at various schemes as in Table 1 and at several values of modulation index $M$. Elimination of triple harmonics is not conducted in this study because they are automatically removed from line-to-line voltage for three-phase power system applications.

The whole steps of the study are summarized by flowchart in Fig. 2.

Table 1. Variation of number of harmonic orders to be minimized

\begin{tabular}{|l|l|}
\hline Scheme 1 & Only $5^{\text {th }}$ harmonic to be minimized \\
\hline Scheme 2 & $5^{\text {th }}$ and $7^{\text {th }}$ harmonics to be minimized \\
\hline Scheme 3 & $\begin{array}{l}5^{\text {th }}, 7^{\text {th }} \text {, and } 11^{\text {th }} \text { harmonics to be } \\
\text { minimized }\end{array}$ \\
\hline Scheme 4 & $\begin{array}{l}5^{\text {th }}, 7^{\text {th }}, 11^{\text {th }} \text {, and } 13^{\text {th }} \text { harmonics to be } \\
\text { minimized }\end{array}$ \\
\hline Scheme 5 & $\begin{array}{l}5^{\text {th }}, 7^{\text {th }}, 11^{\text {th }}, 13^{\text {th }}, \text { and } 17^{\text {th }} \text { harmonics to } \\
\text { be minimized }\end{array}$ \\
\hline Scheme 6 & $\begin{array}{l}5^{\text {th }}, 7^{\text {th }}, 11^{\text {th }}, 13^{\text {th }}, 17^{\text {th }}, \text { and } 19^{\text {th }} \text { harmonics } \\
\text { to be minimized }(\text { as appeared in }(4))\end{array}$ \\
\hline
\end{tabular}

\section{RESULTS AND DISCUSSION}

The simulation results comprise switching angles obtained by GA optimization and the resulting THD along with the FFT of the output voltage waveform. Fig. 3 shows the THD versus modulation index. As can be seen in Fig. 3, there is no strict relationship between the obtained THD and the number of minimized harmonic orders. For example, at $M=0.7$, the lowest THD, i.e. $4.65 \%$, is obtained with Scheme 3, that is when only $5^{\text {th }}, 7^{\text {th }}$, and $11^{\text {th }}$ harmonics are minimized. On the other hand, Scheme 6, which is the most complicated scheme, does not give satisfying THD value of 5.36\%.

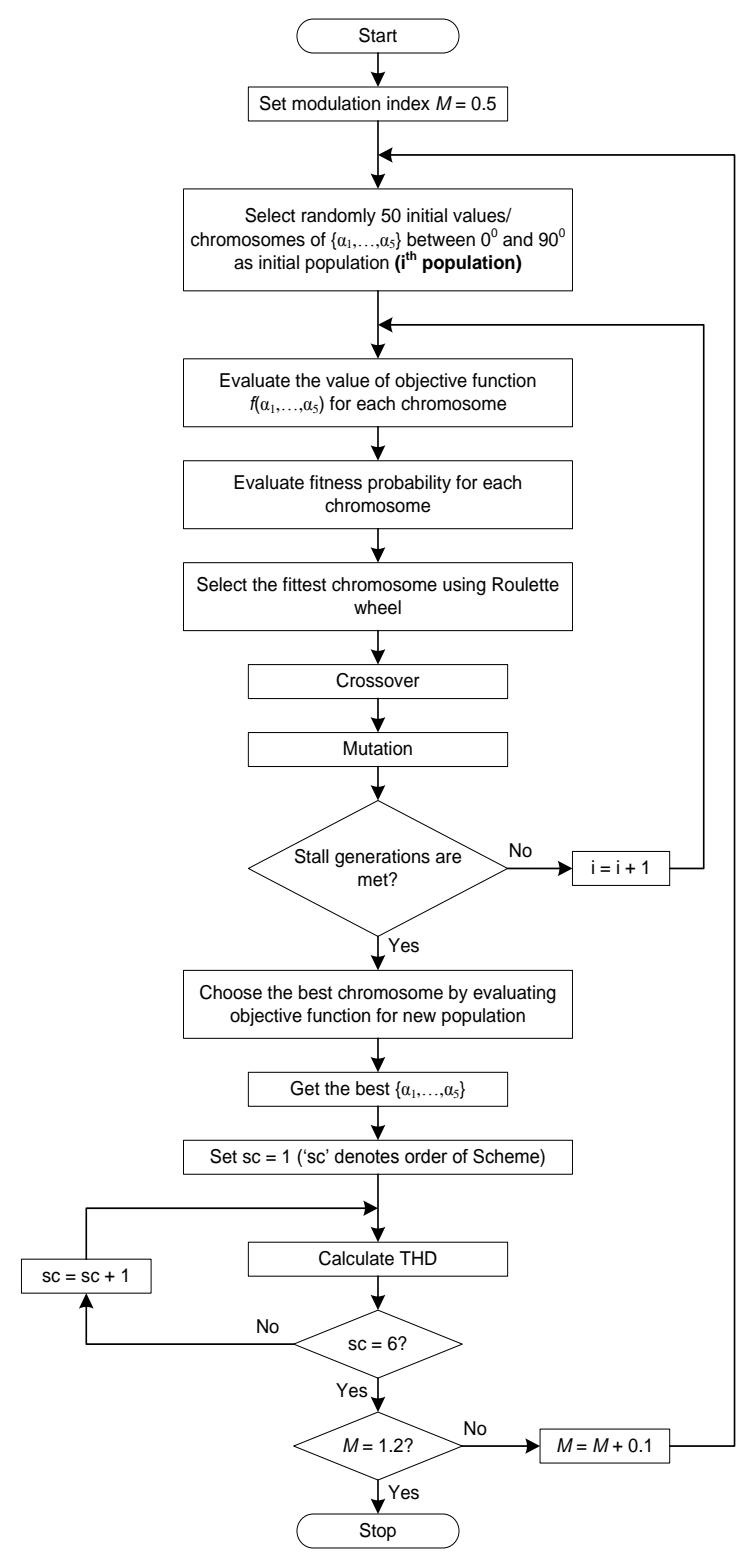

Figure 2. Flowchart of the study

For all $M$ values, the worst THDs are obtained when only single or double harmonics are minimized, i.e. minimization with Scheme 1 or Scheme 2. This, as expected, is logical and reasonable since they are the simplest schemes. For example, at $M=0.5$, the worst THD is $8.51 \%$ (obtained with Scheme 1), at $M=0.6$, the worst THD is $8.56 \%$ (Scheme 1), at $M=1$, the worst THD is $6.39 \%$, and so forth.

Almost in line with the case of the worst THD, in several $M$ values, the lowest THD is achieved when higher number of harmonic orders are minimized, i.e. minimization with Scheme 5 or Scheme 6. This is obvious in Fig. 3 
at $M=1.1$ and $M=1.2$. The lowest THD for both $M$ values are $3.03 \%$ and $2.76 \%$, respectively. The values of switching angle for these cases are listed in Table 2, while Figs. 4 and 5 present their FFT representations, which are evaluated until $20^{\text {th }}$ harmonic. As seen from FFT analysis in Figs. 4(a) and 4(b), all odd harmonics up to $20^{\text {th }}$ order have been minimized, resulting in low THD.

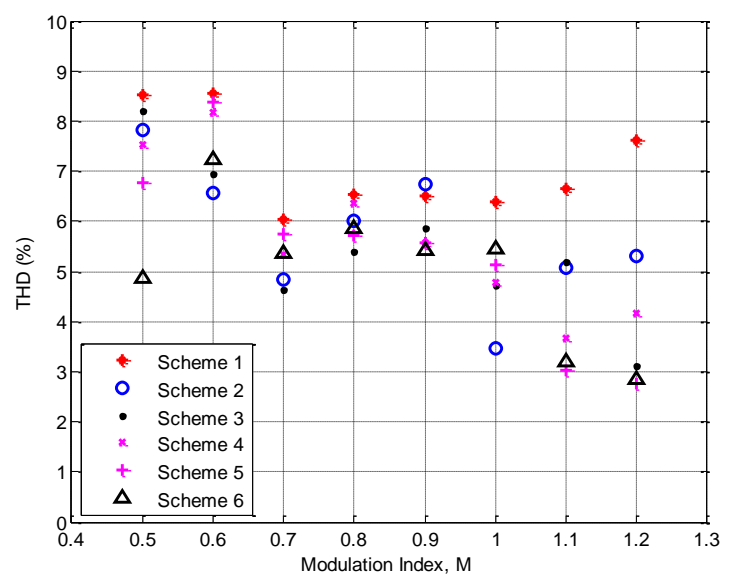

Figure 3. THD versus $M$ for various schemes

Table 2. The values of switching angles for the lowest THD

\begin{tabular}{|c|c|c|c|}
\hline \multicolumn{2}{|c|}{ Case } & $\begin{array}{c}\text { Scheme 5, } \\
M=1.1 \\
(\mathrm{THD}=\end{array}$ & $\begin{array}{c}\text { Scheme 5, } \\
M=1.2 \\
(\mathrm{THD}=\end{array}$ \\
\hline \multirow{5}{*}{ 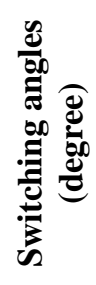 } & $\alpha_{1}$ & 3.62 & 4.00 \\
\hline & $\alpha_{2}$ & 13.93 & 8.82 \\
\hline & $\alpha_{3}$ & 20.68 & 22.48 \\
\hline & $\alpha_{4}$ & 33.74 & 24.57 \\
\hline & $\alpha_{5}$ & 52.51 & 42.47 \\
\hline
\end{tabular}

\section{CONCLUSIONS}

Simulations to minimize harmonics in 11 level multilevel inverter have been conducted with several schemes. Each scheme represents different number of harmonics to be minimized. For each scheme, THD is evaluated until $20^{\text {th }}$ harmonics at various values of modulation index. All optimization processes are automated with MATLAB built-in GA toolbox, which requires only basic MATLAB programming. The following conclusions can be made.

1. The number of minimized harmonics does not strictly determine the obtained THD of the inverter.

2. The highest THD values are obtained, at all modulation index values, when only small number of low-order harmonics, i.e. $5^{\text {th }}$ and $7^{\text {th }}$ harmonics, are minimized.

3. The lowest THD values are obtained, at several modulation index values, when all or most harmonics, i.e. $5^{\text {th }}$ until $19^{\text {th }}$ harmonics, are minimized.

The best obtained THD is 2,76\%, which is achieved with Scheme 5 at $M=1.2$.
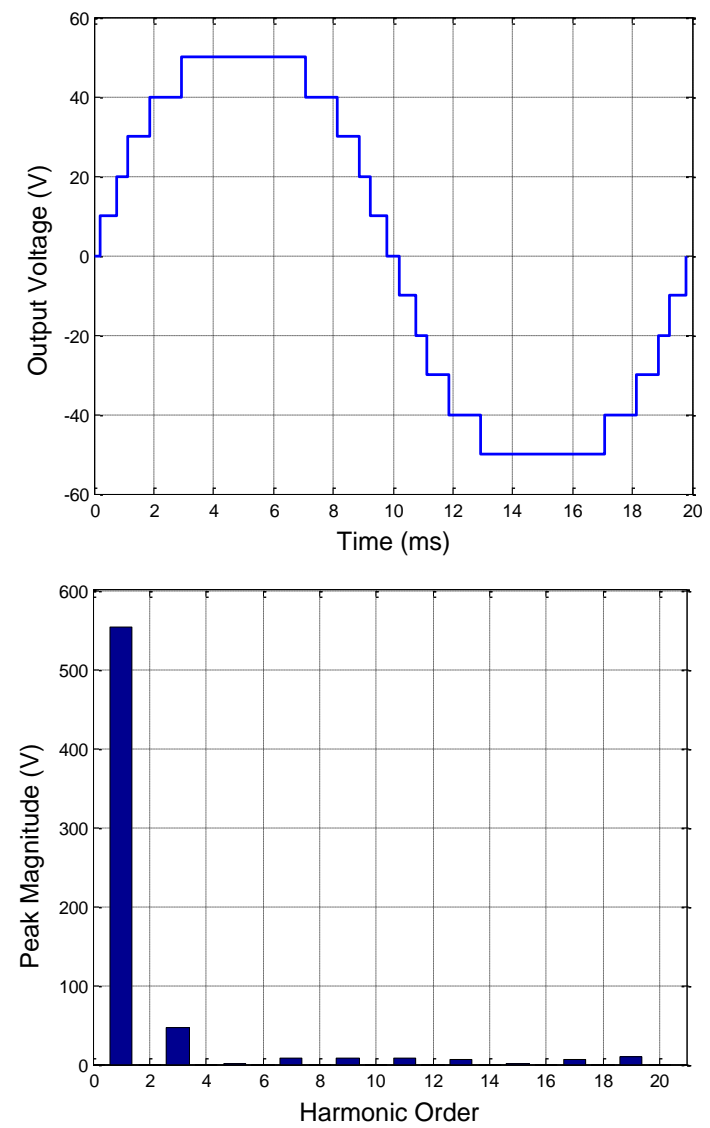

Figure 4. Output voltage waveform and corresponding FFT analysis for Scheme 5 at $M=1.1$ 

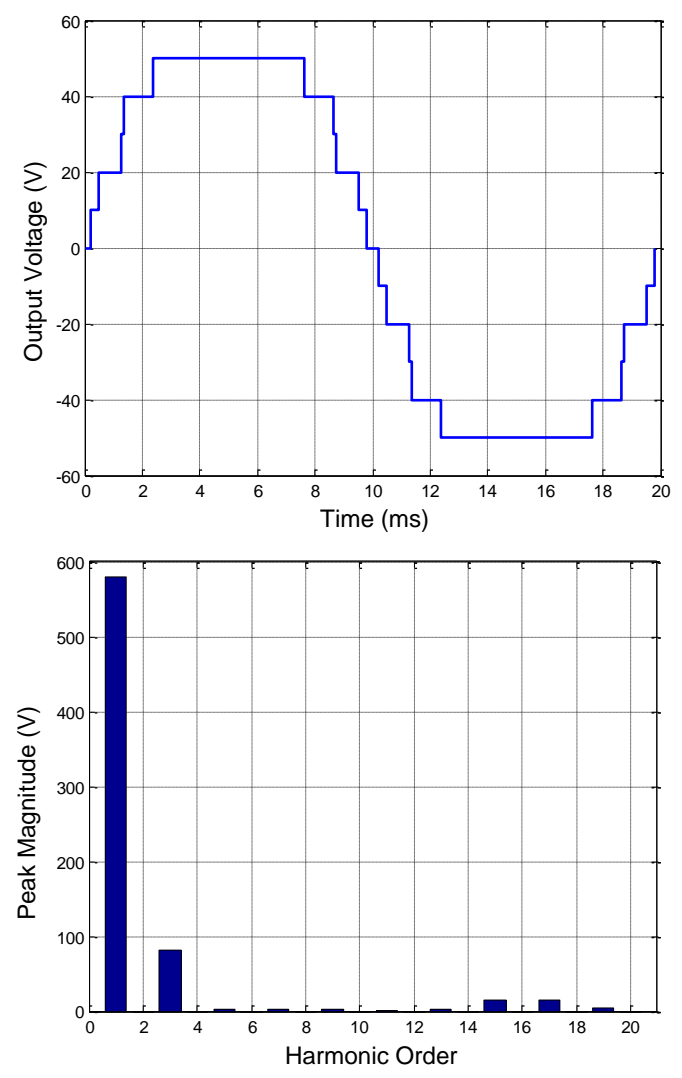

Figure 5. Output voltage waveform and corresponding FFT analysis for Scheme 5 at $M=1.2$

\section{REFERENCES}

[1] K. Kananda and R. Nazir, "Konsep pengaturan aliran daya untuk PLTS tersambung ke sistem grid pada rumah tinggal," Jurnal Nasional Teknik Elektro, vol. 2, no. 2, pp. 65-71, 2013.

[2] D. P. Sari and R. Nazir, "Optimalisasi desain sistem pembangkit listrik tenaga hybrid diesel generator-photovoltaic array menggunakan HOMER (studi kasus: Desa Sirilogui, Kabupaten Kepulauan Mentawai)," Jurnal Nasional Teknik Elektro, vol. 4, no. 1, pp. 1-12, 2015.

[3] L. M. Tolbert, F. Z. Peng, and T. G. Habetler, "Multilevel converter for large electric drives," IEEE Transactions on Industry Applications, vol. 35, no. 1, pp. 36-44, 1999.

[4] J. Rodriguez, J. Lai, and F. Z. Peng, "Multilevel inverters: A survey of topologies, controls and applications," IEEE Transactions on Industrial
Electronics, vol. 49, no. 4, pp. 724-738, 2002.

[5] J. S. Lai and F. Z. Peng, "Multilevel converters - A new breed of power converters," IEEE Transactions on Industry Applications, vol. 32, no. 3, pp. 509-517, 1996.

[6] Z. Du, L. M. Tolbert, and J. N. Chiasson, "Active harmonic elimination for multilevel converters," IEEE Transactions on Power Electronics, vol. 21, no. 2, 2006.

[7] IEEE Std 929-2000, "IEEE Recommended Practices for Utility Interface of Photovoltaic Systems".

[8] M. Manjrekar and G. Venkataramanan, "Advanced topologies and modulation strategies for multilevel converters," in Proc. IEEE Power Electronics Specialists Conference, Baveno, Italy, 1996, pp. 1013-1018.

[9] T. Bruckner and D. G. Holmes, "Optimal pulse-width modulation for three-level inverters," IEEE Transactions on Power Electronics, vol. 20, no. 1, pp. 82-89, 2005.

[10] P. N. Enjeti, P. D. Ziogas, and J. F. Lindsay, "Programmed PWM techniques to eliminate harmonics: A critical evaluation," IEEE Transactions on Industry Applications, vol. 26, no. 2, pp. 302-316, Mar./Apr. 1990.

[11] A. M. Amjad and Z. Salam, "A review of soft computing methods for harmonics elimination PWM for inverters in renewable energy conversion systems," Renewable and Sustainable Energy Reviews, vol. 33, pp. 141-153, Feb. 2014.

[12] I. J. Ramerirez-Rosado and J. L. BernalAgustin, "Genetic algorithms applied to the design of large power distribution systems," IEEE Transactions on Power Systems, vol. 13, no. 2, pp. 696-703, 1998.

[13] B. Ozpineci, L. M. Tolbert, and J. N. Chiasson, "Harmonic optimization of multilevel converters using genetic algorithms," IEEE Power Electronics Letters, vol. 3, no. 3, pp. 92-95, 2005.

[14] D. Kumar, S. Pattnaik, and V. Singh, "Genetic Algorithm Based Approach for Optimization of Conducting Angles in Cascaded Multilevel Inverter," International Journal of Engineering 
Research and Application, vol. 2, issue 3, pp. 2389-2395, 2012.

[15] M. T. Hagh, H. Taghizadeh, and K. Razi, "Harmonic minimization in multilevel inverters using modified species-based particle swarm optimization," IEEE Trans. Power. Electron., vol. 24, no. 10, pp. 2259-2267, 2009.

\section{Author's Biography}

Firmansyah Nur Budiman, completed his undergraduate in electrical engineering at Universitas Gadjah Mada, Yogyakarta in 2009. He received M.Sc. degree in electrical power from King Saud University, Riyadh, Saudi Arabia in 2013. Currently, he is a lecturer at Department of Electrical Engineering, Universitas Islam Indonesia, Yogyakarta. 